\title{
Overeducation in Egypt and its Impact on Labour Market and Unemployment, Higher Education (Case Study)
}

Mehany Ghanaiem, Hend Kamal Abdual Shafy

College of Education Mansoura University, Mansoura, Egypt.

DOI:

\begin{abstract}
The current research aims at answering a major question: What is the reality of overeducation at the higher education level in Egypt \& What's its impact on the labour market ? through presentation of the conceptual framework that deals with the concept of overeducation, indicators and explanatory theories, the shape of the education system in Egypt, the graduate site and the impact of overeducation on the labour market.It also aims at identifying the requirements of balancing the outcomes of higher education (postgraduate studies) with the needs of the Egyptian labour market. The researchers used the descriptive method to present the literature review on research and identify the theories of overeducation. At last, this research is limited to postgraduates studies (master's and doctorate). It also concluded with several recommendations, the most important of which: review the education policy applied by the ministry of higher education with a new view to reduce wastage because of overeducation among Egyptian university graduates.
\end{abstract}

Key words: Higher education, Overeducation, Inadequated education, Over skills.

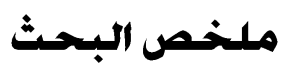

يهاف البحث الحالي إلى الإجابة عن سؤال رئيسي: ما حقيقة التعليم المفرط بالنسبة لمخرجات التعليم العالي في مصر وما هو تأثيره على سوق العمل؟ من خلال عرض الإطار المفاهيمي الذي يتعامل مع مفهوم التعليم المفرط والمؤشرات والنظريات التفسيرية وشكل نظام التعليم في مصر وموقع التخرج وتأثير التعليم التعليم على سوق العمل، كما يهذف إلى تحديد متطلبات الموازنة بين مخرجات التعليم العالي (الدراسات العليا) مع احتياجات سوق العمل المصري. استخدم الباحثان المنهج الوصفي لمراجعة الأدبيات الخاصة بالبحث وتحديد نظريات الإفراط في التعليم. وأخيراً اقتصر هذا البحث على الاراسات العليا (ماجستير ودكتوراه)، وختم بعدة توصيات من أهمها: مراجعة سياسة التعليم المطبقة من قبل وزارة التعليم العالي بهدف تقليل الفاقد بسبب الإفراط في التعليم. بين خريجي الجامعات المصرية.

\section{Preface}

Egypt, like other Arab and international states, has been significant development and expansion at all levels of education.
Egypt has 28 state universities, 24 private universities, 8 technological colleges, 168 academic and higher institutes and 12 health institutes, with approximately 3 million male and 
female students $(42 \%$ of the theoretical studies sector, $58 \%$ of the practical studies sector) and a quick look at the labour market that shows that higher education graduates are generally unfit (unemployment of higher qualifications) and degrees with more skillsthan the work they perform needs. This results in considerable material and moral waste and results in economic, social and psychological problems. Then, the problem of overeducation seems to be relevant. Some students have also shown that a large number of university graduates, having taken jobs, were found to be disproportionate to the qualifications they held (Dolton \& Vignoles 2000, Sloane et al., 1999). In this context the literature review highlights the overeducation and the under-education phenomenon among graduates of higher education in the labour market, describing it as an educational mismatch between the scientific qualifications they hold and the jobs they perform. This phenomenon has been called overeducation.

The phenomenon of overeducation is associated with several variables, such as wages, job satisfaction and training participation (Verhaest \& Omey 2006) and is associated with a highly qualified person working in a field that does not required it. The persistence and prevalence of this phenomenon is evidence that the market economy is not working properly, or that the supply of labour in the market does not match is demands, which may lead to income inequality and long-term unemployment. Wronowska (2017) and Dalton \& Sils (2008) emphasizes this view that overeducation occurs when there is a contradiction between actual and required levels of education that results in slow professional mobility and a low rate of return on investment in education. This can happen to surplus of university graduates, causing them to accept a job requiring a lower level of qualifications than the one they have received (such as a diploma) because it is faster and easier to access (Melosik 2013).

Moreover, researchers examined the concept of an overeducation and attempted to clarify and explore its dimensions, suggesting that it was limited to an individual educated in excess of the job level (Mehta et al., 2011).

Among others, the concept is related to the difference between the level of education required for filling an employment position (Leuven \& Oosterbeek 2001).

In addition, several literature reviews have examined the concept from different sides, which can be described below:

\section{Literature Review}

\section{Ghosh et al., (2020)}

This article examines the effect of international mobility on the education-job mismatch and skillmismatch of $\mathrm{PhD}$ graduates after controlling for self-selection into cross-border mobility. Using individual -level data from two waves of survey of $\mathrm{PhD}$ recipients in Italy conducted by the Italian National Institute of Statistics, the researchers find migration to foreign countries reduces 
significantly the risk of overeducation and overskilling. They also explore the causal relationship between international mobility and measures of overeducation and overskilling. Using survey data on four cohorts of Italian $\mathrm{PhD}$ recipients, they have found the international migration sizably reduces the odds of education and skill mismatch in the labour market.

\section{Luksyte et al., (2020)}

In this paper, the researchers simultaneously examined the relative applicability of personenvironment fit and relative deprivation theories in explaining the interactive effects of percived overeducation and collectivism cultural orientations on positive outcomes. They hyposized that the negative (positive) influence of perceived overeducation on personenvironment fit (relative deprivation) will be weaker among employees with high collectivisms would explain the hypothesized interactive effects in predicting these workers'citizenship behavior, personal initiative, work engagement and life satisfaction. They tested their hyptheses in two studies. The moderated mediation results supported the idea of personenvironment fit (but not relative depriviation) as the mechnism explaining why collectivism orientations assuaged the negative effects on perceived overqualification on these outcomes.

\section{Garcia et al., (2020)}

The aim of this paper is to analyze the relationship between overqualification and the various dimensions of job satisfaction in Spain, a country characterized by a strongly segmented labour market with high unemployment levels, and a significant number of mismatched employees. Using microdata for a presentative sample of Spanish workers. They carry out simultaneous maximum likehood estimations on a two-equation system to control for potential endogeneity. At last, the results obtained provide evidence that doesn't reject the hypothsis that mismatched workers don't necessarily feel less satisfied than adequately-matched workers in the dimensions of job satisfaction related to extrinsic domains or social relations.

\section{Delaney et al., (2020)}

This study uses quarterly EU Labour Four Survey data for 30 countries over the period 2000 to 2016 to examine the relationship between changes in the composition of educational attainment and overeducation rates among new labour market entrants holding post-secondary and tertiary qualifications. The researchers find that tertiary education expanded rapidly across their sample, while the proportion of young people with lower levels of education fell gradually throughout the period. Despite the significant increases in the percentage of young people educated to tertiary level, overeducation among new tertiary graduates fell. The descriptive evidence also suggests that some of the greatest declines in overeducation of young tertiary graduates occured in the countries experiencing the most significant expansion in tertiary education. Overeducation rates among young graduates with 
upper-secondary and post-secondary (nontertiary) education were lower in magnitude than overeducation of tertiary graduates and declined slightly over the period. Their GMM results confirm the negative relationship between educational expansion and overeducation for both tertiary and post-secondary graduates, and reveal a number of other factors potentially explaining cross-country variation in youth overeducation rates.

\section{Alzubaidi \& Mohamed (2020)}

The purpose of this study is to analyze the impact of overeducation on several job attitudes and outcomes. The study is based on cross-sectional survey data from 398 Saudis in the labour market. The results of the hierarchical regressions suggest that overeducation across the two measures is significantly negatively related to turnover intentions, even after controlling for diffrent confounding variables. However, no significant impact was found for job performance. Furthermore, despite the slight differences in terms of the magnitudes of their effects, the two self-assessment measures of overeducation largely overlap and yield similar conclusion. These findings confirm that expect for job performance, overeducation as a form of person job misfit is an important predictor of job attitudes and outcomes. This current study extends the existing literature by providing coparative empieical evidence on the impact of overeducation in Saudi Arabia.

\section{Sloane et al., (2020)}

This study refered to many college graduates are employed in jobs that neither require a degree nor make full use of skills learned in college. It also displayed the empirical analysis based on crosssection data suggest that overeducation is a sign of market failure. It shed light on studies using panel data indicate that the combination of overeducation and overskilling is most damaging to employees' outcomes. Moreovere, empirical studies using cross-section data find a sigificant wage penalty and a reduction in job satisfaction for overeducated workers.

At last, the findings of this study refered to labour market mismatches (where employee qualifications do not match job requirements or are not used on the job) can result from overeducation or overskilling, which are two distinct phenomena. Policy markers should be especially concerned with overskilling which is likely to be harmful both to the welfare of employees (lower job satisfaction) and the interests of employers (lower productivity). Thus policy should ensure that education policies recognize that they must integrate with policies on skill formation outside the workplace, in case over-production of formal education interacts negatively with skill formation.

\section{Anja Rossenl et al., (2019)}

This study investigates the incidence of overeducation among graduate workers in 21 European Union countries and its underlying factors based on the European Labour Force 
Survey 2016. Although controlling for a wide range of covariates, the particular interest lies in the role of fields of study for vertical educational mismatch. The study reveals country differences in the impact of these factors. Compared to Social sciences, male graduates from, for example, Education, Health and welfare, Engineering, and ICT (Information and Communication Technologies) are less and those from Services and Natural sciences are more at risk in a clear majority of countries. These findings are robust against changes of the standard education. Moreover, some fields show gender-specific risks. We suggest that occupational closure, productivity signals and gender stereotypes answer for these cross-field and cross-country differentials. Moreover, country fixed effects point to relevant structural differences between national labor markets and between educational systems (Rossen 2019).

\section{Marius-Cristian P. \& Mina F. (2019)}

One of the approaches describing the strategic vision initiated by the Europe 2020 Strategy for smart sustainable and inclusive growth considers that increasing public expenses with education can help in achieving its goals. Concomitantly, higher levels of educational attainment are supposed to at least partially offset the negative effects of economic crises. Nevertheless, one of the consequences of this strategic approach-Over education-tends to be underrated. This article aims to analyse the influence of the institutional arrangements of the business environment and labour market on Over education in Romania. For this purpose, we designed two indicators for the institutional quality of business environment and labour market. Their evolutions were compared with the change in the unemployment rate among tertiary graduates. The research reveals that in Romania, the quality of institutional arrangements can still be improved, and that one of its negative consequences is unemployment and an exacerbated number of tertiary graduates in the higher education system. An inverse relationship has been identified between the quality of institutional arrangements of business environment and labour market, on one hand, and the rate of tertiary graduates who never worked in the total unemployed tertiary graduates, on the other hand.

\section{Kucel \& Vilalta (2019)}

Overeducation has been demonstrated to be frequent and persistent across countries. It often goes together with working in a job not related to the field of study (horizontal mismatch) or in a job that requires lower skills than acquired (skill mismatch). We study which program characteristics help university graduates to obtain a good job match. We do the analysis for Spain since the presence of over-education is strong in this country. We analyze the three types of mismatch: overeducation, horizontal mismatch, and over-skills. We focus on the role of program characteristics in avoiding over-education in the first job after graduation, and in exiting overeducation in the early career. We find that those 
programs that are academically prestigious and those that promote entrepreneurial skills help avoid being mismatched in the first job and, in case of being mismatched in the first job, they help exit this situation. Overall, our results give support to policies promoting the development of entrepreneurial skills in the Spanish education system.

\section{Turmo-Garuz (2019)}

Overeducation has usually been considered a phenomenon brought about during integration into the labour market. There is no single explanation, but rather several factors that are associated with Overeducation. We analyse Over education among graduates in Catalonia 4 years after finishing their degrees. The analysis is based on the self-assessment made by workers in surveys conducted by AQU (Catalan University Quality Assurance Agency) between 2008 and 2014 and we use logit and probit statistical models to determine the probability of a graduate being overeducated, depending on a wide range of economic, sociological, technological and academic variables. We use the Heckman methodology in the analysis. This study corroborates the results of previous studies on the relationship between wages, job satisfaction and oover education. In addition, the results show, firstly, differences in levels of Over education between different fields of study, most notably between 'Humanities and Arts' and 'Health Sciences'. Secondly, the results reveal the impact of the economic cycle on Over education.
Thirdly, the variables used in the statistical model exhibit stable behaviour and, as a result, they provide an explanation for overeducation as a structural phenomenon, regardless of the economic situation. Furthermore, other variables show a significant relationship with signalling theory and career mobility theory, which both explain the overeducation phenomenon. We especially emphasise the role of professional career development during undergraduate studies. Additionally, we found that the family socioeconomic environment is relevant in explaining overeducation and, lastly, technological factors and aspects of the graduates' work environment also contribute to explaining the phenomenon.

\section{Munsech, Queralt \& Capsada (2019)}

This article aimed at contributing to the existing methodological debate providing systematic and cross-country evidence on the variation across overeducation measurements. The researcher provided evidence on within and cross-countries variation on the incidence,correlation and overlaps across the main types of objectives,statistical and subjective overeducation indicators. Results also suggested that workers self-reported indicators better cope with comparative studies, while in single-country studies objective indicators are likely to provide a more in depth and detailed measurement. The use of statistical indicators is advised in contexts with labour markets that easily adapt to educational and employment changes,especially if these are not affected by credential inflation. 


\section{Savic \& Maja (2019)}

This article examines overeducation in the UK labour market using Annual Population Survey (APS), 2006 to 2017. It aims at identifying the incidence of overeducation in the UK labour market by sex,age and region $\&$ the relationship between overeducation and wages and if the results for women and men differ.In addition to the increase in the number of individuals attaining a first degree or equivalent.In brief, between 2013 and 2017 the total number of graduates in employment increased by $14.8 \%$. The increase in overeducation could also mirror an increasing competition for higher skilled jobs and surplus of candidates. From 2016 to 2017 the overeducation rate decrease slightly, by less than 2 percentage points, and in 2017 it stood at 16.1\%. Over time,competition amogest graduates may rise the level of education required for the job, hence increasing the threshold.This may lead ti a decrease in the number of overeducated employess.

\section{Vecchi \& Michela (2019)}

This study focused exclusively on wages but there are other job characteristics that workers value, such as flexible hours, desirable location and job security. Agraduate might accept a lower paid job in exchange for some of these features, in which case there is not a real "penalty" for overeducation.Related evidence also shows that an increase in education leads to improved social trust,volunteering and political efficacy,indicating that the benefits of education go beyond wages and individuals' perferences and it can increase welfare in our society. The researcher refers to a discussion in the Guardian claims that education is for life not just for employment prospects,and that individuals will need to be increasingly adaptable to the challenging conditions of the labour market.

\section{Vichet \& Sam (2018)}

This paper devoted a special examination to a direct link between overeducation to a direct link between overeducation and economic growth.It also used two sources of data,a macro data from the world Bank to mainly calculate the economic growth and a micro data from the Integrated Public Use Microdata Series International(IPUMSI) to principally measure the incidence of overeducation.Then,the researchers combine these two data and get an unbalanced panel of thirty-eight developing countries between 1990 and 2011.Hence,this paper contributed to the literature on three main points:

1. Matching a micro and macro data, which allowed analyzing the impact of overeducation on economic growth, while the previous literature on the relation between higher education and economic growth seems to overbook this issue.

2. Setting a light on developing countries where previous researchers mainly focus on developed countries.

3. Dealing with unobserved heterogeneity between countries and endogeneity of 
overeducation that have not been fully resolved in the prior literature.

\section{Pseiridis et al., (2018)}

This study shows that overeducated individuals are often considered as "victims" of labour market misfunctioning, as they are not responsible for the appearance of their overeducation. On the other hand, empirical evidence suggests that overeducation 1 . affects various sectors of an economy, 2. is rather large, in Eu-28 it is around $30 \%$ and 3. is persistent over time in many countries. In this paper, the researchers take a different approach by considering overeducation as a voluntary rational choice taken by individuals when they decided their educational plans. They thus treat education not only as an investment in human capital, but also as a consumption good offering certain nonmonetary (physic and social) benefits to university graduates. This approach suggests that overeducation may not be a temporary phenomenon and it will be higher than anticipated when considering education only as investment.

\section{Ueno \& Koji (2018)}

Some people work in occupations that require lower levels of education than their attained education, and these overeducated workers tend to be less satisfied than those who work in occupations that match their attained education. This study sought to extend the previous finding by answering the following previously unexplored questions: Does the association depend on the level of attained education? /Does perceived career delay account for overeducated workers' lower work satisfaction? Data from U.S. young adults (the National Longitudinal Study of Adolescent to adult Study) showed that the association between overeducation and work satisfaction was limited to severely overeducated workers with high school degrees. These people also assessed their career progress more negatively,which accounted for their lower work satisfaction.Analysis of marginal effects of serve overeducation was strong enough to cancel out the benefit of holding the degree to improve work satisfaction.

\section{Nieto, Sandra \& Ramos, Raul (2017)}

The aim of this paper is to test the individuals'skill heterogeneity theory in Spain using microdata from PIAAC, because it is one of the developed countries supporting the highest overeducation rates and where its adult population holds the lowest level of skills among a set of developed countries. Our hypothesis is that the wage penalty of overeduca- tion in Spain is explained by the lower skill level of overeducated workers. The obtained evidence confirmes this hypothesis but only to a certain context as skills only explain partilly the wage penalty of overeducation.

\section{Meroni, Elena C. \& Toscana, Esperanza V. (2017)}

This paper tests whether overeducation at the beginning of a graduate's job career is a trap into continuing overeducation later on, or a stepping stone to a job that matches the candidate's 
qualifications. The researchers focus on a sample of higher education graduates and shape the decision of accepting an overeducated job in a dynamic treatment framework. They distinguish between apparent overeducation (overeducated only) and genuine overeducation (both overeducated and skills mismatch) and investigate the causal effect of both types of overeducation of future job outcomes. They find evidence that overeducation at the beginning of a career leads to a greater likelihood of being overeducated later on, with no real differences between apparent or genuine over-education. Nonethless, interesting national heterogeneities emerge, with Southern, Eastern and continental graguates facing systemic trap into overeducation (genuine and apparent), while their UK peers are trapped only if they accept their first job immediately after graduation. For Scandinavian graduates, large negative effects are found if they are apparently overeducated for their first job.

\section{Munsech, Queralt \& Capsada (2017)}

This article reviwed the economic literature on overeducation and incorporated the the sociological prespective, understanding overeducation as a disadvantage us from of employment. From acontextual prespective, it is urgent to assess the impact of the recent global economic crisis on overeducation across individuals with different backgrounds and accross countries with different educational and labour market institutions. Moreover, the main challenge remains in expanding understanding of overeducation to include individuals' characteristics, contextualising the characteristics and comparing them across different institutional arrangements to understand overeducation as a form of social satisfaction instead of an inefficient economic situation in labour market.

\section{Shunxian (2016)}

The study investigates the influence of Over education on annual earnings among recent Canadian post-secondary graduates. Using data from the National Graduate Survey - class of 2000, 2005, and 2009/2010, I find that over education is negatively associated with annual earnings. It is economically important and not sensitive to the choice of controls (gender, educational attainment, working experience, region, and occupational choice). Interestingly, the negative correlation between overeducation and earnings is even larger after the financial crisis in 2008. I also discover that through comparing those who have graduated for 5 years to those for 2 years, the penalty, though still significant, is reduced by half. Furthermore, this paper shows that males have more dominant earnings advantages over females', top education as well as professional experience also boost earnings considerably (Shunxian 2016).

\section{Verhaest, Dieter et al., (2015)}

Based on monthly observations of their employment and overeducation status in the first seven years after leaving education, the researchers use optimal matching esquence analysis to construct atypology of entry patterns 
of Flemish secondary education graduates. They find that for a significant number of young people, overeduca-tion conistitutes a persistent problem, affecting about half of the sample for nearly the full observation period. Investegating the risk factors show factors such as, having lower human capital endowment or facing job search constraints enhancing the risk of followdisadvantageous trajectories. A lower reservation wage seems to make being persistently overeducated more likely. Yes, starting as "overeducated" does not necessarily lead to being stuck as overeducated in the rest of the career. About 7 per cent of our sample succeeds in entering an adequate position even after being overeducated for a relatively long period.

\section{Boll, Christina \& Leppin, Julian S., (2014)}

Germany's occupational and sectoral change towards acknowledge-based economy calls for high returns to education. Neverthless, female graduates are paid much less than their male counterparts. The researchers wonder whether overeducation affects sexes differently and whether this might answer for part of the gender pay gap. They decompose total year of schooling in years of over- $(\mathrm{O})$, required $(\mathrm{R})$, and undereducation (U). As ORU earnings estimations based on German SOEP cross-section and panel data indicate, over-education pays off less than required education in the current job even when unobserved heterogeneity is taken into account. Moreover, analysis of job satisfaction and self-assessed overeducation point to some real mismatch. However, overeducation does not matter for the gender pay gap. By contrast, women's fewer years of required education reasonably do, answering for 7.61pp. of the East German (18.7990) and $2.22 \mathrm{pp}$. of the West German (32.98) approximate gap.

Moreover, job biography and the hosehold context affect the gap more seriously in the old Bundeslander than in the new ones. Overall, the west German pay gap almost doubles the East German one, and different endowments answer for roughly three quarters of the approximate gap in the earnings gap among German Graduates is rather shaped by an employment behaviour suiting traditional gender roles and assigned gender stereotypes than being subject to gendered educational in anadequacy. At last, the findings suggest that different components of attained education yield different returns, and that returns furthermore differ between sexes particularly with respect to undereducation.

\section{Diem, Andrea et al., (2014)}

This study uses the Swiss Graduate Survey data to investigate the determinants of job-education mismatch and the associated consequences on earnings whill controlling for various ability and motivation factors, as well as socio-demographic, labour market and institutional characteristics. The results indicate that the likelihood of jobeducation mismatch is significantly influnced by individual performance factors, such as final grades and study duration, and that the phenomenon affects approximately $15 \%$ of uni- 
versity graduates. The study also shows that more than one-quarter of the individuals with a jobeducation mismatch 1 year after graduation are still working in a job that does not require a university degree 4 years later.In monetary terms, job-education mismatch is associated with a yearly wage penalty of approximately $4-10 \%$ in the short to medium term.

\section{Li, Ishuan et al., (2014)}

Overeducation and underemployment are of increasing national concern. Recent research estimates that $48 \%$ of workers are overeducated for their positions. The wage penalty for overeducation varies significantly across majors by gender. Using the American Community Survey, the authers examine the extent of overeducation business-related majors. The article contributes to the literature with detailed results of the wage penalties by gender for each of the 13 businessrelated majors, controlling for occupational and industry classifications. Overall, these authors find the penalty for overeducation among most bussiness-related majors to vary from $4 \%$ to $14 \%$. Over-educated women in business-related majors, however, appear to suffer lower wage penalties com-pared to other majors.

\section{Morano \& Clement P., (2013)}

This paper analyzes the determinants of overeducation in the Italian labour market for workers with an MSc degree, using data from the National Labour Force Survey during the (20062011) period. The results confirm the findings obtained by previous studies regarding the relationship between overeducation and a number of individual variables such as age, nationality, firm size and the nature of the employment relation. The paper then contributes to the existing literature by examining whether labour market conditions affect the likelihood of being overeducated. I find mixed results across age categories, but evidence of a positive relation between unemployment and overeducation for workers below the age of 25 (Morano 2013).

Morano (2013) analyzed the determinants of overeducation in the Italian labour market for workers with an MSc degree, using data from the National Labour Force Survey during the (20062011) period. The results confirm the findings obtained by previous studies regarding the relationship between overeducation and a number of individual variables such as age, nationality, firm size and the nature of the employment relation. He found mixed results across age categories, but evidence of a positive relation between unemployment and overeducation for workers below the age of 25 .

\section{Hock-Eam Lim (2013)}

The objective of this paper is to examine overeducation among Malaysian graduates with focus on its association with predetermined (before they enter the labour market) and current level of overall life happiness. Results reveal that there are a substantial percentage of overeducated graduates. Graduates who reported a higher level of predetermined happiness are less likely to be overeducated. Overeducation is also significantly 
and negatively associated with one's current level of happiness. This finding suggests 'hysterias' of overeducation and supports Job Competition Theory's prediction on persistent of Over education. Thus, happiness might be one of the reasons why Over education is a persistent and durable phenomenon (Hock-Eam Lim 2013).

Hock (2013) try to examine overeducation among Malaysian graduates with focus on its association with predetermined (before they enter the labour market) and current level of overall life happiness. Results reveal that there are a substantial percentage of overeducated graduates. Graduates who reported a higher level of predetermined happiness are less likely to be overeducated. Thus, happiness might be one of the reasons why overeducation is a persistent and durable phenomenon.

\section{Leuven \& Edwin (2011)}

This paper surveyed the economics literature on overeducation. The original motivation to study this topic were reports that the strong increase in the number of college graduates in the early 1970s in the U.S.A led to a decrease in the returns to college education. We argue that Duncan and Hoffman's augmented wage equation-the workhorse model in the overeducation literature in which wages are regressed on years of overschooling, years of required. We discussed measurement and estimation issues and give an overview of the main empirical findings in this literature. Finally, we given an appraisal of the economic lessons learned.

\section{Carrol et al., (2011)}

This paper uses recent panel data from the 2010 Beyond Graduation Survey to analyze the incidence of labour force under-utilisation amongst recent Australian graduates and its effect on their wages, with an under-utilised graduate defined as a one who is in a job for which a sub degree qualification would suffice. The researchers find that $26 \%$ of graduates were under-utilised immediately after course completion and $15 \%$ were under-utilised three years later, although this varied considerably between subgroups. Recent graduates were much more likely to remain under-utilised than become under-utilised later in their careers. Being underutilised appears to affect the earnings of different graduate age groups in different ways. Controlling for unobserved heterogeneity, they find that younger graduates tend to earn the same mean wages regardless of whether or not they are under-utilised, while older under-utilised bachelor's degree graduates are at a significant wage disadvantage relative to their peers. This is suggestive of a graduate skills surplus and, by extension, inefficient public and individual investment in human capital.

\section{Barone, Carlo \& Ortiz, Luis (2011)}

The incidence of overeducation in eight European countries is here assessed by means of multiple indicators. With the exception of Spain, the results reveal that overedu- cation is a minor risk amongst European tertiary graduates.Yet, the contrast between different indicators reveals the 
existence of an overeducation of moderate kind inc countries with high rates of tertiary attainment (Norway, Finland and Netherlands). The results also reveal importance of higher education differentiation for understanding the risk of overeducation. Graduates from humanistic fields,bachelor courses and vocational colleges are more exposed to overeducation, through their disadvantage varies cross- nationally.

\section{Peiro et al., (2010)}

The researchers explored the relationships between overeducation and job satisfaction (extrinsic, intrinsic, social facet) as well as the direct and moderating role of salary, contract of employment and work experience in these relationships using hieravchical regression analysis. Data were collected from a sample of 643 young Spanish employees. As expected, there were negative relationships between overeducation and all 3 satisfaction facets. Moreover, high work experience emerged as a moderating factor that buffered the negative effect of overeducation on extrinsic satisfaction. Contract of employment and salary did not moderate these relationships.

\section{Lengyel et al., (2010)}

This paper aimed at analyzing the problem of overeducation among the gratuate young adults. During this research tried to frame factors influencing the occurrence of overeducation. The main results showed higher rate of young adults belonging to the Romanian ethnic group becoming overeducated compared with the young adults from the Hungarian ethic group. It is also the overeducation is an alternative to unemployment. Analyzing overeducation it is significant for several reasons. The researchers highlighted the negative effects of overeducation which affects not only the individual productivity but has implications on the job satisfaction too. Their results showed that job mismatch has a high probability to result in quitting the job. According to the results, the researchers would encourage the use of distinctive approaches during the examination of overeducation of the graduate Transylvanian young adults including the risk aversion attitude. The new hypothesis framed in this paper could give an alternative path for the reasearch of overeducation among graduate young adults.

\section{McGuinness \& Bennett (2005)}

This paper exploits the homogeneity of data from a cohort of Northern Ireland graduates to explore the extent to which both the incidence and impacts of Over education are specific to individuals of particular ability levels as proxied by their position within the graduate wage distribution. It was found that whilst the incidence of Over education was heavily concentrated within low-ability segments of both the male and female graduate wage distributions, it was by no means exclusive to them. Using quantile regression techniques, it was found that, relative to their well-matched counterparts, lowand midability overeducated male graduates earned substantially less. However, the impacts of Over 
education were found to be much more pervasive and constant throughout the entirety of the female ability (wage) distribution. The results provide only partial support for the hypothesis linking overeducation with lower levels of ability.

\section{Linsle \& Ingrid (2005)}

This paper refers to overeducation was a form of labour underutilization which occurs when the formal education level of a worker exceeds that which is required for the job. In Australia close to 30 per cent of workers are overeducated and are underutilising their skills. Using data from the Negotiating the life courses of overeducation in Australia. Four of the key theories that have been used to explain overeducation are tested: human capital, job competition, assignment and the career mobility theories. Tests show that the job competition model best explains the existence of overeducation in the Australian labour market.

\section{Research Problem}

The number of those admitted to higher education in Egypt is increasing annually, with the result that the number of graduates is not absorbed by the labour market in most specialities. Whether those with bachelor's degrees (initial university graduates) or with master's and doctorate degrees, as a result of which the numbers of unemployd annually (unemployment) have increased, and the following tables show the system of higher education in Egypt.

Table (1) higher education in Egypt in figures (2017/ 2018), initial university degree

\begin{tabular}{|c|c|c|c|}
\hline Status & Total & Govermental & Percentage \\
\hline New & 733.000 & 512.000 & $70 \%$ \\
\hline Enrolled & 2.9 million & 2.24 million & $77 \%$ \\
\hline Graduates & 486.000 & 278.000 & $57 \%$ \\
\hline
\end{tabular}

Source: www.Ministry of Higher Education and Scientific Research: Egypt's tertiary education system. $24^{\text {th }}$., July 2018.

Table (2) shows the rates of enrolment and graduation in Egyptian universities according to academic degrees.

\begin{tabular}{|c|c|c|}
\hline Degree & Enrolled \% & Graguates \% \\
\hline Diploma & 61 & 77 \\
\hline Master & 29 & 16 \\
\hline Doctorate & 10 & 7 \\
\hline Total & 100 & 100 \\
\hline
\end{tabular}

The number of students enrolled in Egyptian universities with higher education (2018/2019) was 240.000 of whom 220.000 or $96 \%$, were in government universities, with degrees as follows:

\section{$61 \%$ Diploma, 29\% Masters, 10\% PhD}

The total number of graduates (2016/2017) is 122.000 of which 118.000 are at public universities, with the following breakdown:

\section{7\% Diploma, 16\% Masters ,7\% PhD}

The data indicate that the highest in postgraduate education, with about $30 \%$ of the total postgraduate enrolment, as well as the higher sector in diploma, account for about $45 \%$ of the total graduate population. The data also indicate that graduation tertiary theoretical sectors account for about $80 \%$ of the total graduate population. In 
literature review for the researcher shed light on the benefits of educational research, a sample of 272 teaching staff and researchers (masters \& $\mathrm{PhD}$ ) from 26 Arab universities (12 Egyptians) and 14 other Arab countries were surveyed to show a lack of return for researchers, especially those with degrees (masters/PhD), who did not improve their professional status (Ghaneim \& Albaha 2019).

\section{Indicators of overeducation in Egypt}

These indicators reflect existence of this problem (the two researchers believe it has become a problem) and may turn into crisis:

- a constant increase in the number of graduates.

- graduate unemployment.

- employment in jobs that are not commensurate with the qualifications of the graduates.

- The qualifications of some graduates are not commensurate with the requirements of the labour market.

- Labour market movement is limited in absorbing graduates even if qualifications are available.

- Weak economic growth curve that drives the labour market to assimilate graduates.

- Many jobs are poorly paid in proportion to the living burdens of graduates.

\section{Ways to measure Overeducation}

Measuring overeducation comes with the difficulties pertaining to empirical work and those derived from the choice of measurement approach and from the definition of the concept.
There are three approaches to measure overeducation: worker self-assessment, statistical analysis and analysis of the job (Chevalier 2003, Verhaest \& Omey 2006, Garca Montalvo \& Peir 2009, Leuven \& Oosterbeek 2011).

Self-assessment is based on workers' responses regarding the suitability of their education level to the requirements of their job, whether through direct or indirect questions (Verhaest \& Omey 2006).

The statistical approach determines the match between the education received and the 'most frequent' education level in the job in question; that is, according to the education level of the people that normally hold that post (Verdugo \& Verdugo 1989). Hence, individuals with an education level that is more than one standard deviation above the mean education level within their occupation would be overeducated.

Analysis of the job takes the qualitative classification of jobs following the ISCED classification as its reference; this way, workers that, according to the standards, show a higher education level than that corresponding to the job in question are overeducated.

Verhaest \& Omey (2006) and Leuven and Oosterbeek (2011) carried out critical analyses of the different approaches. According to these authors, the statistical approach is the least desirable, mainly due to the instability of the standard deviation of education levels in relation to the mean, resulting from variations in labour supply and demand that can affect the average 
education level used for each post. Together with Hartog (2000), these authors consider that the ideal approach would be the analysis of the job, as long as the standards of the job functions are continually updated.

Self-assessment raises the issue that subjectivity can prompt the workers interviewed to overestimate the requirements of the post, which can in turn lead to an underestimation of overeducation (Hartog 2000).

However, given that in this case we are dealing with an analysis carried out at three different times, only the graduates' own assessment of the suitability of their education to the post can provide greater understanding of how the conditions for job match in the labour market are updated over time. Furthermore, the availability of data that allow us to make an immediate and reliable calculation of overeducation is another factor that supports the selection of the selfassessment approach (Turmo-Garuz 2019).

\section{Research Justifications}

- There are graduates 20 years or more in junior university, who did not have a job with their qualifications or who sought and could not find a job.

- Holders of degrees (Masters \& $\mathrm{PhD}$ ) for decades and their job status has not improved, working in jobs that do not require the higher skills they have aquired.

There is no doubt that the long wait for a job, with rapid technical development, has resulted in a skills imbalance in the labour market as a result of this development, and there is nothing wrong with these graduates. According to the previous data, it is very beneficial to the following literature review which is a reason of research justifications:

- Garcia, Inmaculada and Montuenga, Mainar (2020): Over-qualification and the Dimensions of Job Satisfaction"

- Alzubaidi, Mohamed (2020): The Impact of Overeducation on Job Outcomes Evidence from Saudi Arabia"

- $\quad$ Sloane, Peter \& Mavromaras, Kostas (2020): Overeducation, Skill Mismatches, and Labour Market Outcomes for college Graduates"

- Ma, Chao et al (2020): Effects of Perceived Overqualification on career distress and career planning: Mediating Role of Leader Humility"

The fact that the two researchers have cohabited with a number of researchers during their doctoral \& master studies, after obtaining a degree (whether on a job or not), shows that a degree exceeds the requirements of their profession. A degree has not helped those who do not work to obtain a job commensurate with their qualifications. The demonstrates the importance of education. Arab studies in this area (with the exception of two - as far as the two researchers are aware) Hawriya study addressed the employment sector at Tayba university in Saudi Arabia. Also, Alzubydi study, based on a survey of 398 data on the labour market and its impact on job satisfaction in Saudi Arabia. 


\section{The Main Question}

What is the reality of overeducation in Egypt's postgraduate level \& its impact on the labour market?

\section{The Sub-Questions:}

1. What is meant by overeducation \& theories that explain it?

2. What form the education system in Egypt \& What is the site for postgraduate studies of this system?

3. What impact overeducation has on the labour market?

4. What are the requirements for balance the outputs of higher education (postgraduates) with the needs of the Egyptian labour market?

\section{Search limits}

Research is limited to postgraduate studies (Master \& Doctorate).

\section{The Concept of "Overeducation"}

This term is dealt with in Arabic by various nomenclatures (Exaggeration, Over, Increase) all of which perform almost the same meaning. In addition to the two researchers prefer "Overeducation" which is indication of an overeducation by the institution that awards a degree or by an undergraduate or both.

The concept of overeducation is linked to the existence of a certain limit to education as a job requirement, and it is the overreaching of that limit through higher education that gives rise to overeducation and therefore, overeducation implies exceeding the educational limit required for a job.

\section{Theories explain Overeducation}

\section{Human Capital Theory:(HCT)}

This theory understands overeducation appearance as a temporary and negligible mismatch due to imperfect information between workers 'skills and firms 'needs during individuals job searchers. The situation quickly changes because the worker will look for a matched job or the firm will adapt to the worker's education to fully utilise his or her skills and knowledge. HCT assumes that individuals make investments in education in order to use them in the labour market and maximize their utility and wages, while firms are willing to fully utilize worker's skills and knowledge to get the maximum productivity from them. This perspective assumes that both individuals and firms are choosing the best option to get a satisfactory match and no heterogeneity in references is contemplated. An extension of HCT is the matching theory, which has the same argumentation but takes firms into consideration in the search process, also making them responsible for the mismatch.

\section{Job Competition Model (JCM)}

The second theory presents the labour market as constituted by two queues that organize the allocation process: job vacancies and workers. Jobs are ranked hierarchically given the educational level required and other job characteristics. Workers position in the queue 
depends on their education level relative to the rest of the workers. Thus, individuals always have more incentives to invest in education, since they are in a permanent competition for jobs, promoting credential inflation. Individuals with more education get the best jobs, but even workers in the heighest positions might be overeducated if there are no jobs left in the queue the match their education level. Overeducation can become quite a permanent state if no new high-skilled job characteristics determine workers' job allocation. One of the underlying assumptions of this model is that all individuals have the same preferences for jobs, and jobs can only be hierarchically ranked in one form.

\section{Assignment Theory}

Situated between HCT and JCM, the assignment approach stresses that both workers' and firms' characteristics play a role in allocating individuals to jobs. As a first step, individuals choose a sector based on their preferences on wage maximization. After this intermediate step, individuals are allocated to jobs based on their educational level, among other personal characteristics. Thus, contrary to HCT and JCM, allocation is based on a non-random distribution of workers in sectors. Overeducation appears when workers' education exceeds the one required for the job. The mismatch can be solved via individuals' or firms' adjustment some individuals might be willing to stay in an overeducated position if it maximizes firms' and individuals' wage and utility. This approach takes into consideration different preferences among workers on their wage maximization, as well as cross-sector and crossoccupation differences in job characteristics (Munsech 2017).

\section{Career Mobility Theory}

This theory formalized the notion of career mobility as an explanation for the phenomenon of overeducation. The author constructed a model of which the assumptions immediately imply that a worker with given innate ability may prefer to start in a job below his ability level if this compensated by a higher probability to be promoted. This implies that "individuals may consider a lower-level firm in which the direct return to schooling is lower if in those firms-for a given level of schooling, the probability of promotion is higher" (Leuven \& Osterbeek 2011).

\section{Results Discussion}

From the preceding presentation, from reading the data in tables (1) \& (2), from the literature review, it is obvious that the phenomenon of overeducation is constantly increasing, although it has not led to an important in the level of graduates' professions. This phenomenon is a material and moral waste for both students and the state.

\section{Proposed problem-solving Scenarios}

Based on the foregoing, three scenarios are proposed for reducing or eliminating the phenomenon of overeducation: 
- The Reality Scenario (Painful Reality): a continuation of the status quo and recognition of the crisis for some time to come, which may be shortened or prolonged, with negative effect, in order to realize social demand.

- A pessimistic Scenario: reduced admission to higher education, reduced enrolment, negative effects of which are reduced equal opportunities in education and acculturation.

- An optimistic Scenario: to align graduate's qualifications with labour market demands; to make optimal use of graduates' competencies and qualifications, to promote and move professionally in order to achieve material and moral gains for graduates, both those who have wished a job that corresponds to their qualifications and have not been provided with them.

\section{Recommendations}

- Students counseling and professional guidance by raising awareness among students applying to university in general and to graduate studies in particular.

- Labour market mobility (material and moral gain) to make people happy.

- Take scenario the third scenario (optimistic).

- Predictive studies of the labour market requirements for masters and $\mathrm{PhD}$ degrees.

- Review the education policy applied by the ministry of higher education with a new view to reduce wastage because of overeducation among Egyptian university graduates.
- To promote the harmonization of higher education outcomes with the demands of the labour market by building a nationwide database and information on the numbers of enrolements and graduates in educational institutions and on the labour market requirements of graduates in all the different displines and fields of education.

- In response to the growth of the labour market and the educational services sector and the growing desire for higher education, an atmosphere of harmony should be created between the labour market and education policy, through the creation of new and diversified jobs that match the qualifications of graduates and the development of a reward for work culture that makes them competitive for all.

\section{References}

Al Zaubaidi, Mohamed A., 2020.The Impact of Overeducation on Job Outcomes: Evidence from Saudi Arabia, International Journal of Research in Business and Social Science, 9(4): $104-120$.

Available at: $\underline{w w w . s s b f n e t . c o m}$

(www.Researchgate.net)

Boll, Christina, Leppin, Julian S., 2014. Overeducation among Graduates: An Overlooked Facet of the Gender Pay Gap? Evidence from East and West Germany, SOEP papers on Multidisciplinary Panel Data Research at DIW Berlin.

Available at: http://www.diw.de/soeppapers www.Researchgate.net 
Barone, Carlo, Ortiz, Luis, 2011. Overeducation among European University Graduates: A comparative Analysis of its Incidence and the Importance of Higher Education Differentiation, Higher Education, Vol. 61: 325 - 337.

www.link.springer.com

Delaney, Judith et al., 2020. Educational Expansion and overeducation of Young Graduates: A comparative Analysis of 30 European Countries, Oxford Review of Education, 46: 10-29.

Available at: www.Tandfonline.com

http://doi.org/10.1080

Diem, Andrea, Wolter, Stefan, C., 2014. J. Labour Market Res., 47: 313-328. www.link.springer.com

Dolton P. J., Silles M. A., 2008. The effects of over-education on earnings in the graduate labour market. Economics of Education Review, 27(2): 125-139.

Hock-Eam Lim, 2013. Overeducation and Happiness in The Malyaysian Graduate Labour Market, International Journal of Business and Society, 14(1): $93-110$.

Ghosh, Sucharita, Grassi, Emanuele, 2020. Overeducation and Overkilling in the Early Careers of $\mathrm{PhD}$ Graduates: Does International Mismatch?. papers in Regional Science, Vol. 99(4)

Available at: www.onlinelibrary,wiley.com $\underline{\text { https//doi.org/10.11.1111/pirs.12509 }}$

Hurn C. J., 1993. The limits and possibilities of schooling: An introduction to the sociology of education, Pearson College Division.

Kucel, Aleksander, Vilalta, Montserrat, 2019. University Program Characteristics and Education-
Job Mismatch. The B. E. Journal of Economic Analysis \& Policy, Vol. 19: Issue 4.

DOI: https://doi.org/10.1515/bejeap-2019-0083

Published online: 17 Sep 2019.

Lengyel, Gyorgy, Csata, Zsombor, 2010. Examination of the Causes of Overeducation among Graduate Young Adults in Transylvania, Remarking the Social, New Risks and Solidarities, The First International Conference of the Sociology and Social Work,"Babes-Bolyai" University Cluj-Napoca 2-4 December, 2010. Economic Actors and Attitudes in the Making. Available at: www.cluj2010.files.wordpress.com

Leuven E., Oosterbeek H., (2011). Overeducation and mismatch in the labor market. In Handbook of the Economics of Education. 4: 283-326.

Li, Ishuan et al., 2014. Overeducation and Underemployment Mismatch: Wage Penalties for College Degrees in Business, The Journal of Education for Business. 90: 119 - 125.

www.Researchgate.com

Linsley, Ingrid, 2005. Causes of Overeducation in the Australian Labour Market,

Available at: www.Researchgate.net

Luksyte, Aleksandra et al., 2020. Perceived Overqualification and Collectivism Orientation: Implications for Work and Nonwork Outcomes, Journal of Management.

Available at: www.Researchgate.net

Ma, Chao et al., 2020. Effects of Perceived overqualification on Career Distress and Career Planning Mediating Role of Career of Leader 
Humility. Human Resourse Management, Vol. 59, Issue (6). Available at: www.Researchgate.net

Mainer, Inmaculada G., Montuenga, Victor M., 2020. Overqualification and the Dimensions of Job Satisfaction, Social Indicators Research, 147(1): $591-620$. Available at: www.link.springer.com

Marius-Cristian Pana, Mina Fanea-Ivanovici, 2019. Institutional Arrangements and Overeducation: Challenges for Sustainable Growth. Evidence from the Romanian Labour Market.

Massimiliano, Tani, David Carrol, 2011. Labour Market Undre-Utilisation of Recent High Education Graduates: New Australian Panel Evidence, IZA Discussion Paper No, 6047.

www.anon-ftp.iza.org

McGuinnessa, S'amu, Bennettb, Jessica, 2005. Overeducation in the graduate labour market: A quantile regression approach Economics of Education Review 26 (2007) 521-531.

Mavromaras, Kostas, Sloane, Peter J., 2020. Overeducation, Skill Mismatches, and Labour Market Outcomes for College Graduates, IZA world of Labour, wol.iza.org.

Mehta A., Felipe J., Quising P., \& Camingue S., 2011. Overeducation in developing economies: How can we test for it, and what does it mean? Economics of Education Review, 30(6): 13341347.

Melosik Z., 2013. Edukacja uniwersytecka i procesy stratyfikacji społecznej. KulturaSpołeczeństwo-Edukacja, 3(1): 21-46.
Meroni, Elena C., Toscano, Esperanza V., 2017. The Persistence of Overeducation among Recent Graduates, Labour Economics, (4): 120-143.

Available at: www.sciencedirect.com http://doi.org/10.1016

Morano, Clement P., 2013. The Determinants of Overeducation: Evidence from the Italian labour market, "New Skills and Occupations in Europe: Challenges and possibilities", organized by the Centre for European Policy Studies (CEPS) in Brussels, November, 2013, 25 - 27.

Munsech, Queralt C., 2019. Measuring Overeducation: Incidence, Correlation and Overlaps across Indicators and Countries, Social Indicators Research, Vol. (145): 279-301.

Munsech, Queralt C., 2017. Overeducation: Concept, Theories and Empirical Evidence, Sociology Compass, Vol. 11(4), September, 2017, Project: Overeducation from a Social Satisfaction Prespective. Available at: www.Researchgate.net

Nieto, Sandra, Ramos, Raul, 2017. Overeducation, Skills and Wage Penalty Evidence for Spain Using PIAAC Data, Social Indicators Research, Vol (134), February 2017, $219-236$.

www.link.springer.com

Peiro, Joes M., et al., 2010. The Relationship between Overeducation and Job Satisfaction among Young Spanish Workers: The Role of Salary Contract of Employment and Work Experience, Journal of Applied Social Psychology, Vol. 40(3): $666-689$.

Avalaible at: www.researchgate.net 
Pseiridis, Anastasia, et al., 2018.Overeducation of University Graduates: Avoluntary and Rational Choice of Individuals.The Case of Three Greek Universities, Scientific Research Publishing, Theoritical Economics Letters (TEL), 8:(11) 21352156. http://www.scirp.org/journal/tel. Available at: www.researchgate.net

Rossen et al., 2019. Patterns of Overeducation in Europe: The Role of Field of Study, IZA Journal of Labor Policy.

Savic, Maja 2019. Overeducation and hourly Wages in the UK Labour Market; 2006 to 2017, Office for National Statistics.

Available at: https://www.ons.gov.uk

Sicherman N., Galor O., 1990. A theory of career mobility. Journal of political economy, 98(1): 169192.

Shunxian Yu, 2016. Overeducated Graduates in the Canadian Labour Market.

Available at: dc.identifier.uri

http://hdl.handle.net/10393/35136

Thurow L., 1972. Education and economic equality. The Public Interest, 28. Verhaest, D., \& Omey E. (2010). The determinants of overeducation: different measures, different outcomes? International Journal of Manpower, 31(6). Wronowska, G. (2017). Overeducation in the labour market. Ekonomia i Prawo. Ecomomics and Law, 16(2): 219-228.

Turmo-Garuz, Joaquin et al., 2019. Factors Associated with Overeducation Among Recent Graduates During Labour Market Integration: The Case of Catalonia (Spain).

https://doi.org/10.1007/s11205-019-02086-za

Ueno, Koji, Krause, Alexandra, 2018. Overeducation, Perceived Career Progress, and Work Satisfaction in Young Adulthood, Research in Social Stratifiction and Mobility, (55): 51-62 Available at: www.sciencedirect.com https://doi.org/10.1016/j.rssm

Vecchi, Michela, 2019.Overeducation in the UK Labour Market, Middlesex University London, mdxminds.com/201

Verhaest, Dieter et al., (2015). Overeducation in the Early Career of Secondary Education Graduates: An Analysis Using Sequence Techniques, SAGE journals, Journals.sagepub. com. First published, October 16, 2015. Available at: www.google.com.eg (http://doi.org/10.1177)

Vichet Sam, 2018. (Overeducation among Graduates in Developing Countries: What Impact on Economic Growth?. (MPRA) Munich Personal RePEc Archive, IAE Savoie Mont Blance, Royal University of Law and Economics. https://mpra.ub.uni-muenchen.de/87674/ 